\title{
Lactic Acid Bacterial Fermentation Feed as Basal Ration: Addition Effect of Protein and Carbohydrate Protection on Rumen Fermentation of Bligon Goat
}

\author{
Moh. Ikmal Khoirozzadit Taqwa ${ }^{1}$, Zaenal Bachruddin ${ }^{1, *}$, Lies Mira Yusiati ${ }^{1}$, \\ Nafiatul Umami ${ }^{2}$, and Muhlisin Muhlisin ${ }^{1}$ \\ ${ }^{1}$ Laboratory of Nutritional Biochemistry, Faculty of Animal Science, Universitas Gadjah Mada \\ Jalan Fauna No. 3, Kampus UGM, Bulaksumur, Yogyakarta, Indonesia, 55281 \\ ${ }^{2}$ Laboratory of Forages and Pasture, Faculty of Animal Science, Universitas Gadjah Mada \\ Jalan Fauna No. 3, Kampus UGM, Bulaksumur, Yogyakarta, Indonesia, 55281 \\ "Corresponding author. Email: bachrudin@ugm.ac.id

\begin{abstract}
This study aims to examine the influence of feed heating on the volatile fatty acid (VFA), microbial protein, and ammonia concentrations in rumen fluid. The feed ingredients are a carbohydrate supply (corn), and a protein source (soybean meal) added to the basal ration through lactic acid bacteria fermentation. The livestock employed were Bligon goats weighing 25-29 kg and aged 1.5-2 years, fed by a combination of grass, concentrate (70:40), and additive feed. The present study was based on an in vivo examination of ruminal digestibility. The data were analyzed statistically using a split-plot design with two components. The first factor was feed treatment, which includes heating (soaking feed in $90^{\circ} \mathrm{C}$ water for five minutes under ambient air pressure) and non-heating. The second factor was ruminal fermentation time, consisting of 0 hours before and five hours after feeding. Sampling was done after treatment for two months. Each treatment was carried out with three replications. The results showed that heating did not significantly affect the total levels of VFA, acetate, propionate, butyrate, ammonia, and microbial proteins production. The fermentation time significantly affected the increase in propionate and butyrate fractions, but not for the total VFA levels, acetate fraction, ammonia, and microbial proteins. Propionate tended to increase by $55.52 \%$ for heated feed and $37.84 \%$ for non-heating feed. Butyrate tended to increase by $56.77 \%$ for heated feed and $26.32 \%$ for non-heating feed. Meanwhile, feed heating (non-heating) tended to cause a lower total VFA of $36.51 \%$ (60.54\%), acetate of $23.43 \%$ (73.32\%), ammonia of $17.98 \%$ $(60.10 \%)$, and microbial protein of $4.17 \%(10.74 \%)$. This study concluded that heating carbohydrate and protein as additive feed sources had not significantly affected changes in VFA, microbial protein, and ammonia levels. However, the heating effect tended to reduce the increase in total VFA levels, microbial protein acetate, and ammonia levels of rumen fermentation.
\end{abstract}

Keywords: Lactic acid bacteria, carbohydrate and protein protection, volatile fatty acids, ammonia, and microbial protein

\section{INTRODUCTION}

The success of the livestock industry is determined by the quality of the feed, especially the value of protein and carbohydrates contained in the feed. On the other hand, feed costs account for about $80 \%$ of production costs [1,2].

Energy source cereals, e.g., corn and wheat, contain starch readily fermentable in the rumen. Therefore, it will cause a rapid accumulation of short-chain fatty acids (SCFA) in the rumen $[3,4]$.
This SCFA load can cause acidosis, also known as subacute ruminal acidosis (SARA) [5] S, and if the rumen $\mathrm{pH}$ drops to around 5 , it will cause acute ruminal acidosis (ARA) [6,7]. [8,9] stated that acute ruminal acidosis and subacute ruminal acidosis are serious metabolic diseases in livestock with digestive disorders.

Digestive disorders include bloating [10], laminitis [3], liver abscesses [11], and polioencephalomalacia [12] in cattle. In addition, the disease will cause less than optimal livestock performance and reduced animal 
welfare. As a result, it will harm livestock productivity. Besides, ruminants usually only absorb a small amount of feed glucose in the small intestine because most of the starch in feed ingredients is degraded and fermented in the rumen. Therefore, ruminants must go through the mechanism of gluconeogenesis to accomplish daily glucose needs. Growth and production can be further enhanced if glucose is directly infused postruminally $[13,14,15]$, increasing milk production $[15,16]$.

Protein source feed ingredients are necessary because they are related to the supply of essential amino acids and glucogenic amino acids in good quality protein to increase livestock productivity. One example of this feed ingredient is soybeans. Both soybean meal and raw soybean are excellent sources of RDP (rumen degradable protein) and can increase microorganisms in the rumen as a source of $\mathrm{N}$ needed to promote their growth $[17,18]$. Soy protein has good lysine and histidine content and a high digestibility [19,20], but soybeans have low Methionine content (1.44 to $1.47 \%$ CP) can be degraded extensively ( $\geq 57.4$ to $69.6 \%$ ) by rumen microbes [20]. [21] explained that methionine, valine, and isoleucine are limiting amino acids in soybeans. These amino acids can contribute quantitatively and (or) qualitatively to the supply of EAA (essential amino acids). As a plant protein commonly used for animal feed, SB (soybean) has the highest percentage of essential amino acids (47.6\%) as a percent crude protein [22], but SB and SBM (soybean meal) have relatively low protein efficiency due to its high ruminal degradation rate. It is estimated that only $25 \%$ to $34 \%$ of the protein in SB and SBM escapes rumen fermentation [23]. It is a limiting factor in using these feed ingredients as ruminant animal feed, especially those with high productivity. Therefore, increasing soy protein (amino acids) that escapes microbial fermentation activity or is protected in the rumen becomes very important for beef and dairy producers. These limitations underlie the need for methods to reduce the degradability of ruminant protein in soybeans.
Based on the above conditions, it is necessary to optimize the processing and utilization of feed ingredients used mainly for ruminants because the nutrients in the feed, especially protein and carbohydrates, undergo enzymatic hydrolysis by rumen microbes. This optimization is expected to provide good quality feed, especially those containing essential and glucogenic amino acids. On the other hand, as livestock productivity increases, it will impact more glucose to maintain high production yields such as milk and meat. Therefore, in response to some of the above, it is necessary to study the bypass of starch (soluble sugar) and protein in feed to protect these nutrients from degradation and rumen microbial fermentation, which will increase the supply of starch (soluble sugar) and protein into the abomasum and small intestine to be digested and absorbed as amino acids and glucose [24].

Therefore, it is necessary to do protection through heating to increase the amount of glucose that can be metabolized through sugar bypass and the amount of protein (amino acids) through protein bypass. Also, it is expected to have a significant effect on weight gain, reduce the risk of SARA and ARA, efficient use of feed, and increase production of milk and meat in both quality and quantity. Furthermore, heating carbohydrate and protein feed sources effectively bypass enzymatic hydrolysis and fermentation by rumen microbes. Heating carried out in this study is a simple technique by immersing hot water at $90^{\circ} \mathrm{C}$ for 5 minutes in a mixture of protein and carbohydrate source feed ingredients given as feed additives.

\section{MATERIAL AND METHODS}

\subsection{MATERIALS}

The livestock used in this study were eight male Bligon goats with an average weight range of 25 to 29 $\mathrm{kg}$ and an average age of 1.5 to 2 years. These were divided into two treatments. The ratio used in this study was peanut straw and concentrate of fermented lactic

Table 1. Nutrient content of the feed

\begin{tabular}{|l|c|c|c|c|c|}
\hline Feed & BK (\%) & PK (\%) & LK (\%) & SK (\%) & ME (Kcal) \\
\hline Tofu dregs $^{3}$ & 66,23 & 20.49 & 6.41 & 22.68 & 3183 \\
\hline Pollard $^{2}$ & 86.00 & 16.10 & 3.28 & 6.73 & 2210 \\
\hline Coarse bran $^{4}$ & 86.00 & 12.00 & 13.00 & 6.80 & 2887 \\
\hline Soybean meal & 86.00 & 41.30 & 4.90 & 5.30 & 2256 \\
\hline Soybean hull & 88.98 & 6.32 & 1.31 & 34.26 & 2397 \\
\hline Peanut straw & & 15.10 & 6.12 & 22.70 & 2517 \\
\hline Milled yellow corn & & 95.00 & 4.30 & 3.30 & 3361 \\
\hline
\end{tabular}

Description

1. [25]

2. Results of Nutritional Biochemistry Laboratory Analysis, Faculty of Animal Science, Universitas Gadjah Mada (2010)

3. Results of Animal Feed Science Laboratory Analysis, Faculty of Animal Science, Universitas Gadjah Mada (2006)

4. [26]

5. Results of Animal Feed Science Laboratory Analysis, Faculty of Animal Science, Universitas Gadjah Mada (2015) 
acid bacteria consisting of silage, soybean meal, and soybean hull. Silage feed ingredients consist of tofu dregs, pollard, coarse bran, vitamins, minerals, molasses, and starter. The amount of ration given is $10 \%$ of the animal's weight, consisting of $60 \%$ forage and $40 \%$ fermented concentrate feed.

The nutrient content of the feed showed in Table 1. The formula used to produce lactic acid bacterial fermentation concentrate (KFBAL) as basal feed showed in Table 2. All ingredients are mixed and fermented for two weeks. The results of KFBAL fermentation are used to make ration formulas added with soybean meal and hull. The feed ration formula used can be seen in Table 5. The ration formula made had a PK content of $14.55 \%$ and a BK content of $71.87 \%$. The additive feed weighted 300 grams and contained $70 \%$ milled corn as a carbohydrate source and $30 \%$ soybean meal as a protein source.

Table 2. Formulation of lactic acid bacteria fermented concentrate feed ingredients

\begin{tabular}{|l|l|l|}
\hline No & Feed Ingredients & Amount used $(\mathrm{kg})$ \\
\hline 1. & Tofu dregs & 39.0 \\
\hline 2. & Pollard & 29.5 \\
\hline 3. & Coarse bran & 29.25 \\
\hline 4. & Vitamin & 0.25 \\
\hline 5. & Mineral & 0,25 \\
\hline 6. & Molasses & 1 \\
\hline 7. & Starter & 0.5 \\
\hline Total & & 99.5 \\
\hline
\end{tabular}

Table 3. Concentrated ration formula used as basal feed

\begin{tabular}{|l|l|c|}
\hline No & Formula & Percentage (\%) \\
\hline 1 & $\begin{array}{l}\text { Lactic acid bacteria } \\
\text { fermented concentrate }\end{array}$ & 43.17 \\
\hline 2 & Soybean meal & 18.76 \\
\hline 3 & Soybean hull & 38.07 \\
\hline
\end{tabular}

\subsection{METHODS}

This research was conducted based on a split-plot design consisting of two factors. The first factor (main plot) is the feed treatment which consists of two subtreatments. The second factor is the sampling time (subplot), i.e., 0 hours before and 5 hours after feeding. Sampling was carried out after treatment for two months. Four cattle were used as replication for each feed treatment (main plot), and after feeding treatment for two months, rumen fluid samples were taken at 0 hours before feeding and 5 hours after feeding.

Feed treatment consists of two kinds. Bligon Goat with rations were given additional feed by heating as the first treatment. Bligon Goat with rations were given additional feed without being heated in the second treatment. Each treatment used four cattle as replication. Heating is done using milled feed ingredients (carbohydrates) and soybean meal (protein) first mixed until homogeneous in an open container (air pressure adjusts to the surrounding environment), then the mixture of feed ingredients is immersed in hot water at $90^{\circ} \mathrm{C}$ for 5 minutes with the ratio between water and feed mixture is $2: 1$. The non-heating treatment of the feed was carried out by immersing the mixture of feed ingredients into cold water at a temperature of $25^{\circ} \mathrm{C}$ to $27^{\circ} \mathrm{C}$ with a ratio between water and feed ingredients mixture was 2:1.

Samples of rumen fluid were taken from six Bligon goats, namely three goats with heating treatment and three goats without heating treatment. Sampling was carried out at two different times, i.e., before feeding in the morning and five hours after feeding. First, rumen fluid is taken through the goat's mouth using a unique tube and pumped out. The rumen fluid is then collected and placed in a bottle with the ear tag number labeled. The rumen fluid sample is then taken to the Nutritional Biochemistry Laboratory, Faculty of Animal Science, UGM, to analyze VFA, microbial protein, and ammonia levels.

The data obtained were analyzed for variance according to the split-plot design. The main plot is feed treatment, while fermentation time (sampling time at 0

Table 4. pH, acetic acid content, propionic butyrate, and total VFA with feed heating factor

\begin{tabular}{|l|c|c|c|c|}
\hline \multirow{2}{*}{ Parameter } & \multicolumn{2}{|c|}{ Heating } & \multicolumn{2}{c|}{ Non-heating } \\
\cline { 2 - 5 } & $\begin{array}{c}\text { (0 hours) before } \\
\text { feeding }\end{array}$ & $\begin{array}{c}\text { (5 hours) } \\
\text { after feeding }\end{array}$ & $\begin{array}{c}\text { (0 hours) before } \\
\text { feeding }\end{array}$ & $\begin{array}{c}\text { (5 hours }) \\
\text { after feeding }\end{array}$ \\
\hline $\mathrm{pH}^{\text {ns }}$ & 6.95 & 6.30 & 7.20 & 6.67 \\
\hline Total VFA $^{\text {ns }}(\mathrm{mMol} / \mathrm{L})$ & $36.92 \pm 18.25$ & $45.99 \pm 8.88$ & $33.75 \pm 4.04$ & $53.77 \pm 19.95$ \\
\hline Asetat $^{\text {ns }}(\mathrm{mMol} / \mathrm{L})$ & $25.34 \pm 13.56$ & $29.12 \pm 6.65$ & $22.90 \pm 3.18$ & $39.22 \pm 18.14$ \\
\hline Propionate $^{\text {ns }}(\mathrm{mMol} / \mathrm{L})$ & $7.82 \pm 0.615$ & $11.33 \pm 2.96$ & $7.68 \pm 3.10$ & $10.67 \pm 1.23$ \\
\hline Butyrate $^{\text {ns }}(\mathrm{mMol} / \mathrm{L})$ & $3.77 \pm 1.62$ & $5.54 \pm 1.27$ & $3.17 \pm 0.283$ & $3.88 \pm 0.80$ \\
\hline
\end{tabular}

Description

Ns: not significant $(\mathrm{P}>0.05)$. 
and 5 hours) is a subplot. All statistical analyses and calculations were performed using Statistical Product and Service Solution (SPSS) personal computer software version 22.0 from IBM

\section{RESULTS AND DISCUSSION}

Data on the results of total VFA levels and each fraction for feed treatment with heating and nonheating sub-treatments and fermentation times of 0 hours and 5 hours are presented in Table 4.

The results of analysis of variance in Appendix 1 showed that heating concentrates of protein and carbohydrate source feed ingredients at 0 and 5 hours of fermentation did not significantly affect changes in the $\mathrm{pH}$ value of rumen fluid fermentation $(\mathrm{P}=0.36)$. Furthermore, based on the statistical analysis results, the protection of carbohydrate and protein source feed ingredients by heating using water at $90^{\circ} \mathrm{C}$ did not significantly differ between feed with heating and nonheating treatment to decrease the rumen $\mathrm{pH}$ value $(\mathrm{P}=0.70)$. Thus, it indicated that the rumen conditions in all treatments were normal and ideal for rumen microbes to ferment substrates because the rumen buffering system (maintaining $\mathrm{pH}$ values in the normal range) worked.

The degree of acidity or $\mathrm{pH}$ of the rumen fluid is a balance between the buffer capacity and the alkaline or acidic nature of the fermentation product. All treatments in this study showed a significant decrease in $\mathrm{pH}$ value after 5 hours of feeding $(\mathrm{P}=0.02)$. Treatment with heating feed caused a decrease in $\mathrm{pH}$ value of $9.3 \%$, and non-heated feed caused a decrease of $7.3 \%$. This decrease was caused by the fermentation of the dissolved substrate from the feed into VFA. The accumulation of VFA will cause a decrease in the rumen $\mathrm{pH}$ value. It follows the opinion of [27], who explained that one of the causes of the decrease in the $\mathrm{pH}$ of the rumen fluid is the rapid fermentation of soluble carbohydrates, which causes the rapid VFA accumulation.

[28] added that the increase in VFA in the rumen causes the $\mathrm{pH}$ value of the rumen fluid to decrease. [29] explained that a decrease in the $\mathrm{pH}$ value occurred between 1 to 4 hours after feeding. Therefore, fluctuations in the $\mathrm{pH}$ value of the rumen fluid during the study were within normal limits and still suitable for rumen microbial activity. This result is consistent with [30], who claims that in an anaerobic rumen environment, the normal $\mathrm{pH}$ of the rumen fluid is 6.0 to 7.0 at $38^{\circ} \mathrm{C}$ to $41^{\circ} \mathrm{C}$. This result is supported by [31,32], who explained that the optimal range of $\mathrm{pH}$ values for rumen microbial activity ranged from 6 to 7. [33] also stated that fluctuations in rumen $\mathrm{pH}$ values ranged from 6.3 to 7. 7.0, which was described by [34]. [29] where the fluctuation was caused by changes in the number of organic acids accumulated in the rumen, the amount of saliva, the amount of $\mathrm{NaHCO} 3$ and phosphate.
The analysis of variance in Appendix 2 showed that the interaction between feed treatment and fermentation time did not significantly affect the total concentration of VFA $(\mathrm{P}=0.448)$. The same results were obtained for each VFA fraction: acetic, propionic, and butyric acids $(\mathrm{P}=0.34 ; \mathrm{P}=0.37 ; \mathrm{P}=0.25$. Therefore, based on the statistical analysis results, the protection of carbohydrate and protein source feed ingredients by heating (using water at $90^{\circ} \mathrm{C}$ ) did not significantly reduce total VFA levels and their fractions.

The effect of fermentation time ( 0 and 5 hours), total VFA levels, tended to increase after 5 hours of feeding both heated and non-heated feed $(\mathrm{P}=0.82)$, as well as the levels of each VFA fraction (acetate, propionate, and butyrate), there was a significant increase in the levels of propionic and butyric acids $(\mathrm{P}=0.023 ; \mathrm{P}=0.027)$ but not for acetic acid $(\mathrm{P}=0.15)$. The tendency to increase VFA levels was since after feeding the feed substrate was fermented by rumen microbes, one of the products was VFA. It is explained by [35], who stated that VFA production reflects the degradability of organic matter, including carbohydrates in the rumen.

Rumen microbes mainly degrade carbohydrates into acetic, propionic, and butyric acids and isobutyrate and isovaleric, short-chain fatty acids as VFA components. In addition, microorganisms will utilize volatile fatty acids from carbohydrate fermentation by rumen microbes as an energy source and form a carbon skeleton. It can be seen in the acid levels before and 5 hours after feeding, where there was an increase in levels (although statistically, the fermentation time did not show a significant difference for total VFA for each VFA fraction). Table 5 presents the rate of change in total VFA levels and their fractions with heating treatment.

Table 5. The rate of change in total VFA levels and each fraction by heating treatment

\begin{tabular}{|l|c|c|}
\hline \multirow{2}{*}{ Parameter } & \multicolumn{2}{|c|}{ Treatment } \\
\cline { 2 - 3 } & Heating & Non-heating \\
\hline Total VFA & $36.51 \%$ & $60.54 \%$ \\
\hline Acetic acid & $27.43 \%$ & $73.72 \%$ \\
\hline Propionic acid & $55.52 \%$ & $37.84 \%$ \\
\hline Butyric acid & $56.77 \%$ & $23.32 \%$ \\
\hline
\end{tabular}

Table 5 shows that total VFA levels tended to increase by $36.51 \%$ for the heated feed and $59.32 \%$ for the non-heated feed (although statistical analysis of the increase in total VFA levels between the heated and non-heated feeds did not show a significant difference. The acetic acid content increased by $27.43 \%$ for the heated feed and $73.72 \%$ for the non-heated feed. Changes in propionic acid levels for feed with heating and non-heating were $55.52 \%$ and $37.84 \%$, respectively, while butyric acid levels for feed with heating and non-heating were $56.77 \% \quad 23.32 \%$, 
respectively (analysis of The increase in levels of each VFA fraction).

Feed heating in this study generally tends to reduce the total VFA levels compared to non-heating $(36.51 \%$ vs. $59.32 \%$, although statistically not significantly different). Heating feed tends to cause a decrease in acetic acid content but also tends to cause an increase in propionic and butyric acid levels (although statistically not significantly different, statistical analysis of the comparison of the level of change in levels of each VFA fraction). Theoretically, heating causes gelatinization of starch and will increase its degradation rate in the rumen. The results showed that the levels of propionic and butyric acids tended to have a greater increase in levels in the heated feed $(55.52 \%$ vs. $37.84 \%$, for propionic and $56.77 \%$, and $23.32 \%$ for butyrate). It is following the opinion of [36], which has been confirmed by [37], who explained that heat treatment generally causes an increase in the rate of starch degradation in the rumen in situ. However, under certain conditions, proper heating techniques in feed can reduce VFA production because proper heating conditions will cause complex compounds between sugar and protein to reduce the rumen's degradation level. Under the argument of [38], who stated that heat treatment could reduce starch digestibility due to the formation of sugar-protein complexes. [39] added to this statement by revealing that, although sugar and protein complex bonds occur, it is unknown how much similar complexes can be formed. It is also unknown whether rumen microbes can hydrolyze these complexes and make starch available for rumen fermentation, but the results of a study by [40] showed that there was no difference in the degree of rumen starch degradation or total digestibility between fresh and heated corn. [41] stated that heating affects the level of rumen degradation, and whether it will increase or decrease the level of degradation depends not only on the temperature and duration of heating but also heating technique, type of feed, and animal species.

As for what causes heating using $90^{\circ} \mathrm{C}$ water does not provide a significant level of VFA reduction with non-heated feed, are technical factors, temperature, and heating time. The temperature used is not high enough to completely change the structure of carbohydrates into the retrograde phase, so many amylopectin molecules are degraded first by enzymatic activity in the rumen. [42] stated that sufficient heat would be able to reduce the level of digestibility of starch in the rumen to a low level, so that it will be able to increase the supply of starch (glucose) into the small intestine, but the level of digestibility in the rumen will continue to decrease along with the increase. Therefore, the toohigh temperature will cause the starch to experience overprotection.

The retrogradation phenomenon of amylopectin compounds to become structures with low solubility levels takes a long time, while this study used a 5 minute heating time so that not many amylopectin molecules have not entered the retrogradation phase. It is in accordance with the opinion [43], which explains that the retrogradation phenomenon in amylopectin takes a long time to develop so that the compound resulting from the retrogradation process is resistant to the enzymatic activity of rumen microbes.

Other factors such as variations in heating techniques also influence the rate of starch bypass. As the study conducted by [42], dry heating (without pressure) or dry roasting at a temperature of $110^{\circ} \mathrm{C}$ will increase the digestibility of sugar in the rumen, while heating (dry roasting) using a temperature of $130^{\circ} \mathrm{C}$ and $150^{\circ} \mathrm{C}$ reduces the amount of dissolved sugar fraction so that the level of sugar can be dissolved. The digestibility of sugar in the rumen will decrease, but heating sugar with pressure toasting techniques such as research conducted by [41] results in a significant increase in sugar bypass $27.6 \%, 31.7 \%, 40.0 \%$, and $48.7 \%$ at temperatures of $100^{\circ} \mathrm{C}, 118^{\circ} \mathrm{C}$, and $136^{\circ} \mathrm{C}$. [37] also reported the results of their research, that only autoclaving for 30 minutes, there was an increase in sugar bypass and only occurred at the highest temperature (i.e., $145^{\circ} \mathrm{C}$ ) compared to non-treatment (degradation rate 0.175 vs. 0.110 per hour). Autoclaving for 60 minutes, both at temperatures of $130^{\circ} \mathrm{C}$ and $145^{\circ} \mathrm{C}$, caused an increase in the rate of sugar degradation. Based on the descriptions of several researchers above, the combination of temperature, heating time, and pressure is the main factor in the starch bypass process in feed rations.

The results of the study by [37] also showed that heat treatment did not cause a decrease in the rate of starch degradation, although the least intensive heat treatment $\left(15 \mathrm{~min}\right.$ at $\left.115^{\circ} \mathrm{C}\right)$ only showed a weak trend $(\mathrm{P}=0.20)$ towards this effect. Walhain et al. (1992)

Table 6. Microbial protein and ammonia levels with feed heating factor.

\begin{tabular}{|l|c|c|c|c|}
\hline \multirow{2}{*}{ Parameter } & \multicolumn{2}{|c|}{ Heating } & \multicolumn{2}{c|}{ Non-heating } \\
\cline { 2 - 5 } & $\begin{array}{c}\text { (0 hours) before } \\
\text { feeding }\end{array}$ & $\begin{array}{c}\text { (5 hours }) \\
\text { after feeding }\end{array}$ & $\begin{array}{c}\text { (0 hours) before } \\
\text { feeding }\end{array}$ & $\begin{array}{c}\text { (5 hours }) \\
\text { after feeding }\end{array}$ \\
\hline Microbial protein ${ }^{\mathrm{ns}}(\mu / \mathrm{ml})$ & $0.099 \pm 0.03$ & $0.10 \pm 0.02$ & $0.090 \pm 0.02$ & $0.096 \pm 0.02$ \\
\hline Ammonia $(\mathrm{mg} / 100 \mathrm{ml})$ & $12.80 \pm 4.20$ & $14.23 \pm 4.80$ & $9.47 \pm 2.00$ & $14.60 \pm 0.60$ \\
\hline
\end{tabular}

Description

Ns: not significant $(\mathrm{P}>0.05)$. 
reported that the extrusion method at $140^{\circ} \mathrm{C}$ was able to increase the rate of starch degradation in the rumen very high. Pressure toasting for 3 minutes at $132^{\circ} \mathrm{C}$ was able to reduce the degradation of rumen starch in situ to the rumen in whole grains [44], but later [45] reported results that grinding and pelleting treatments would increase the rate of starch degradation in the rumen.

Compared with the technique used in this study, the temperature used is still too low, and the heating time is not long enough. Likewise, the air pressure used during the heating process of the ration has the same pressure value as the ambient air pressure, so the combination of these three factors causes the starch bypass yield obtained from heating the ration to be insignificant.

Data on the results of microbial protein content for feed treatment with heating and non-heating subtreatments and fermentation times 0 hours and 9 hours are shown in Table 6 .

The analysis of variance showed that the heating treatment of feed did not significantly affect the concentration of ammonia and microbial protein $(\mathrm{P}=0.41$ and $\mathrm{P}=0.403$, Appendix 8). Based on the statistical analysis results, carbohydrate and protein source feed heating did not significantly affect ammonia and microbial protein levels. Ammonia and microbial protein levels tended to increase after 5 hours of fermentation, both heated and non-heated feed, although statistically, the fermentation time did not show a significant difference $(\mathrm{P}=0.18$ for ammonia and $\mathrm{P}=0.26$ for microbial protein, Appendix 8). It is in accordance with [46], who stated that the high protein content of feed and easily degraded protein would increase ammonia concentration in the rumen. (47) added that the output of nitrogen metabolism in the rumen consists of ammonia, non-degradable protein (RUP), and microbial protein so that after feeding concentrates, whether heated or not, there was an increase in levels between before and after (although in Statistical fermentation time 0 hours and 5 hours also did not show a significant effect, Appendix 8). The following is presented in Table 7 the level of change in total VFA levels and their fractions with heating treatment.

Table 7. Changes in levels of ammonia and microbial protein with heating treatment

\begin{tabular}{|l|c|c|}
\hline \multirow{2}{*}{\multicolumn{1}{|c|}{ Parameter }} & \multicolumn{2}{c|}{ Treatment } \\
\cline { 2 - 3 } & Heating & Non-heating \\
\hline Ammonia & $17.89 \%$ & $60.10 \%$ \\
\hline Microbial protein & $4.17 \%$ & $10.74 \%$ \\
\hline
\end{tabular}

This study showed that protection by heating techniques did not significantly affect the reduction of ammonia and microbial protein levels. However, if viewed based on the data presented in Table 7, regarding the analysis of the magnitude of changes in ammonia and microbial protein levels, livestock with heated feed resulted in ammonia and microbial protein (between 0 and 5 hours of fermentation) tend to be lower when compared to livestock with unheated feed. It can be proven that the ammonia level tends to increase by $17.89 \%$ for the heated feed and $60.10 \%$ for the unheated feed (Appendix 9). The tendency of lower ammonia levels in the heated feed also led to a lower tendency to increase microbial protein. An increase in ammonia levels of $17.89 \%$ tends to increase microbial protein levels by $4.17 \%$. In comparison, an increase in ammonia levels of $60.10 \%$ tends to increase microbial protein levels by $10.74 \%$ (Appendix 9).

Heating using water at $90^{\circ} \mathrm{C}$ in the rations used in this study seemed to protect the protein from rumen microbial degradation through the Maillard reaction (although statistically the results obtained did not show a significant difference, where the solubility the yield of this reaction is lower. [48] explained that heat would cause Maillard or non-enzymatic reactions between sugar aldehyde groups and free amino acid groups from proteins to produce sugar-amino complex compounds. This complex is more resistant to enzymatic hydrolysis reactions in the rumen, and the reversibility of this reaction depends on temperature and time of heat exposure.

[49] added that the reaction between amino groups and reducing sugars through heat treatment could decrease the rate of protein degradation in the rumen and increase the supply of postrumen metabolizable feed protein. It can be seen in rations with non-heating treatment, which produce higher ammonia and microbial protein (although statistically, the results do not show a significant difference).

The results of the insignificant changes in levels were caused by several factors, one of which was the ecological condition of the rumen, where the ammonia produced by the rumen microbes had been converted into microbial protein and partly had been absorbed by the rumen wall before sample analysis was carried out. Likewise, with microbial protein that has already flowed out of the rumen, although the feed treated with $90 \mathrm{oC}$ heating produced lower ammonia concentrations, the difference in values obtained was not significant after statistical analysis. This result follows the opinion $[50,51]$, who explained that ammonia in the rumen comes from various sources. These sources include feed degradation of protein sources and feed NPN hydrolysis, urea hydrolysis, and microbial protoplasm degradation. This ammonia formation aims to be absorbed by rumen microbes as a source of $\mathrm{N}$ and supply it to the liver as raw material for urea synthesis.

[47] also added that the essential factors influencing protein degradation by rumen microbes include the type of protein, the interaction of the protein with other nutrient content (especially $\mathrm{CHO}$ in the same feed ingredients and the rumen), and the dominant rumen microbial population (depending on the type of ration, rumen flow rate, and $\mathrm{pH}$ ). In addition, protein solubility 
is a critical factor in determining the enzymatic activity of microbial proteases and the degree of degradability of these proteins as substrates.

The results showed that although there was a change in ammonia levels, the ammonia levels in this study ranged from 9.47 to $14.60 \mathrm{mg} / 100 \mathrm{ml}$. According to the recommendations of [52], these levels were still within the normal range, which stated that the ammonia concentration needed by rumen microbes to digest feed optimally was 5 to $20 \mathrm{mg} / \mathrm{dL}$, equivalent to 3.57 to $14.28 \mathrm{mM}$. The $5 \mathrm{mg} / \mathrm{dL}$ of ammonia concentration is equivalent to $3.57 \mathrm{mM}$ [53]. [54] added that an ammonia concentration of about 2.2 to $13.3 \mathrm{mg} / 100 \mathrm{ml}$ is required to develop rumen microbes; an ammonia concentration of about $2.0 \mathrm{mg} / 100 \mathrm{ml}$ can be used for optimal microbial growth. Therefore, at an 8.0 $\mathrm{mg} / 100 \mathrm{ml}$ rumen concentration, microbial biosynthetic capacity has been maximally achieved. [46] explained that fluctuations in ammonia levels in the rumen also depend on the protein content of the feed. The high protein content of the feed and its easily degraded protein will increase the concentration of ammonia in the rumen.

\section{CONCLUSION AND SUGGESTION}

The heating of carbohydrate-sourced feedstuffs and protein-sourced feedstuffs as feed additives has not shown a significant effect on changes in VFA levels of microbial protein and ammonia. However, the effect of heating these feedstuffs tends to decrease the degradation and fermentation processes in the rumen, causing a decrease in the increase in total VFA level, microbial protein acetate, and ammonia.

\section{REFERENCES}

[1] Omar J. 2002. Effects of feeding different levels of sesame oil cake on performance and digestibility of Awassi lambs. Rum. Res. 46:187-190.

[2] Baqain, A.B., and A.V. Zárate. 2011. Economic Analysis of Bedouin Sheep Farming in Jordan and the Palestinian Territories. Livestock Research for Rural Development. 23 (12): 1-10

[3] Nocek, J.E. 1997. Bovine acidosis implications on laminitis.J. Dairy Sci. 80, 1005-1028.

[4] Aschenbach, J.R., Penner, G.B., Stumpff, F., Gabel, G. 2011. Ruminant Nutrition Symposium Role of fermentation acid absorption in the regulation of ruminal $\mathrm{pH}$. J. Anim. Sci. 89:1092-1107.

[5] Stone, W.C. 2004. Nutritional approaches to minimize subacute ruminal acidosis and laminitis in dairy cattle. J. Dairy Sci. 87: E12-E26.

[6] Owens, F.N., Secrist, D.S., Hill, W.J., Gill, D.R. 1998. Acidosis in cattle: A review. J. Anim. Sci.76:275-286.
[7] Nagaraja, T.G and Titgemeyer, E.C. 2007. Ruminal acidosis in beef cattle: The current microbiological and nutritional outlook. J. Dairy Sci. 90, E17-E38.

[8] [8] Plaizier, J.C.; Krause, D.O.; Gozho, G.N., McBride, B.W. 2008. Subacute ruminal acidosis in dairy cows: The physiological causes, incidence, and consequences. Vet. J. 176:21-31.

[9] Calsamiglia, S., Blanch, M., Ferret, A., Moya, D. 2012. Is subacute ruminal acidosis a $\mathrm{pH}$ related problem? Causes and tools for its control. Anim. Feed Sci. Technol. 172, 42-50.

[10] Wang, Y., Majak, W., McAllister, T.A. 2012. Frothy bloat in ruminants: Cause, occurrence, and mitigation strategies. Anim. Feed Sci. Technol. 172:103-114.

[11] Nagaraja, T.G and Lechtenberg, K.F. 2007. Liver Abscesses in feedlot cattle. Vet. Clin. Food Anim. 23:351-369.

[12] Karapinar, T., Dabak, M., Kizil, O. 2010. Thiamine status of feedlot cattle fed a high concentrate diet. Can. Vet. J. 51, 1251-1253.

[13] Van Kessel, J.S. P.C. Nedoluha, A. WilliamsCampbell, R.L. Baldwin, and K.R. McLeod. 2002. Effects of ruminal and post ruminal infusion of starch hydrolysate or glucose on the microbial ecology of the gastrointestinal tract in growing steers. J. Anim. Sci. 80:3027-3034.

[14] Baldwin, R.L., K. R. McLeod, J.P. McNamara, T.H. Elsasser, and R.G. Baumann. 2007. Influence of abomasal carbohydrates on subcutaneous, omental, and mesenteric adipose lipogenic and lipolytic rates in growing beef steers. J. Anim. Sci. 2007. 85:2271-2282

[15] Knowlton, K.F., T.E. Dawson, G B. Huntington, B. P. Glenn, and R.A Erdman. $1998 . \quad$ Glucose Metabolism and Milk Yield of Cows Infused Abomasally or Ruminally with Starch. J. D. Sci. Vol. 8,(12): 3248-3258.

[16] Throckmorton, J.C., and R.A. Leng. 1991. Effect of bypass protein or bypass starch on milk yield and body weight gain in grazing dairy cows. J. Anim. Sci. 15:628-630.

[17] Stern, M. D., K. A. Santos, and L. D. Satter. 1985 Protein degradation in rumen and amino acid absorption in small intestine of lactating dairy cattle fed heat-treated whole soybeans. J. Dairy Sci. 68:45-56.

[18] Tice, E. M., M.L. Eastridge, dan J.L. Firkins. 1993. Raw soybeans and roasted soybeans of different particle sizes. 1. Digestibility and utilization by lactating cows. Journal of Dairy Science. 76:224-235.

[19] Santos, F.A.P., F.E. P. Santos, C.B. Theurer, and J.T. Huber. 1998. Effects of rumen-undegradable protein on dairy cow performance: A 12-year literature review. J. Dairy. Sci. 81:3182-3213. 
[20] NRC. 2001. Nutrient Requirements of Dairy Cattle. 7th rev. ed. Natl. Acad. Sci. Washington, DC.

[21] Schingoethe, D.J. 1996. Balancing the amino acid needs of dairy cows. Anim. Feed. Sci. Tech. 60:153.

[22] Schwab, C. G. 1995. Protected proteins and amino acids for ruminants. In: Biotechnology in Animal Feeds and Animal Feeding (Ed. R. J. Wallace and A. Chesson). V. C. H. Press, Weinheim, Germany. pp. 115-141.

[23] NRC. 1989. Nutrient Requirements of Dairy Cattle. 6th rev. ed. Natl. Acad. Sci. Washington, DC.

[24] Agrarwissenschaften. 2015. Dietary strategies to optimize energy and glucose supply to lactating dairy cows. Dissertation. Institut für Tierwissenschaften

[25] NRC. 1994. Nutrient Requirements of Poultry. 9th Ed. rev. ed. Natl. Acad. Sci. Washington, DC.

[26] Hartadi, H., Reksohadiprodjo, S., Tillman, A. D. 2005. Indonesian Feed Composition Tables. Universitas Gadjah Mada Press, Yogyakarta.

[27] Viera, D.M. 1986. The Role of Ciliate Protozoa in Nutri on of the Ruminant. Journal of Animal Science. 63: 1547-1560.

[28] Kerley, M.S., G.C. Fahey, J.R., L.L. Berger dan N.R. Merchen. 1987. Effects of treating wheat straw with $\mathrm{pH}$-regulated solutations alkaline hydrogen peroxideon nutrient digestion by sheep. Journal of Dairy Science. 70 : 2078-2084.

[29] Owen, F.N., dan A.L. Goetsh. 1988. Ruminal fermentation, in : D. C. Church (Ed), the ruminant animal digestive physiology and nutrition. Prentice Hall. Englewood Cliffs, New Jersey.

[30] Church, D. C. 1979. Digestive Physiology and Nutrition of Ruminants. Volume 1. 2. Oxford Press, Portland.

[31] Owens, F. H. and W. G. Bergen. 1983. Nitrogen metabolism of ruminant animals: historical perspective, current understanding and future implication. Journal of Anim Science. 57: 498518.

[32] Grant R.J., Mertens D.R. 1992. Influence of buffer $\mathrm{pH}$ and raw corn starch addition on in vitro fiber digestion kinetics, J. Dairy Sci. 75. 2762-2768.

[33] Ørskov. 1992. Protein Nutritional in Ruminant. Academic Press, London.

[34] [34] Soejono, M. 1996. Analisis dan Evaluasi Pakan. Petunjuk Laboratorium. Fakultas Peternakan UGM,

[35] Arora, S.P. 1989. Microbial digestion in ruminant. India Council of Agricultural Research. New Delhi.
[36] Offner, A.; Bach, A.; Sauvant, D., 2003. Quantitative review of in situ starch degradation in the rumen. Anim. Feed Sci. Technol., 106 (1-4): 81-93.

[37] Sveinbjörnsson, J., M. Murphy, P. Udén. 2007. In vitro evaluation of starch degradation from feeds with or without various heat treatments. J. Anim. Feed. Sci. Technol. 132:171-185.

[38] Ljokjel, K.O.M. Harstad, E. Prestlokken, dan A. Skrede. 2003. In situ digestibility of starch in barley grain (Hordeum vulgare) ad peas (Psiumsativum L.) in dairy cows: influence of heat treatment and glucose additions. Animal Feed Science and Technology. 107:105-116.

[39] McAllister, T.A., dan K.J. Cheng. 1996. Microbial strategies in the ruminal digestion of cereal grains. Animal Feed Science. 62: 29-36.

[40] Zinn, R., dan R. Barrajas. 1997. Comparative ruminal and total tract digestion of a finishing diet containing fresh vs. air-dry steam-flaked corn. Journal of Animal Science. 75:1704-1707.

[41] Yu, P. 1995. Influence of pressure toasting on rumen degradation characteristics of horse beans in lactating dairy cows. M.Sc. Thesis. Wageningen Agricultural University, The Netherlands.

[42] Yu, P., A.R. Egan, J.H.G. Holmes, and B.J. Leury. 1998. Influence of roasting of whole faba bean (Vicia faba) on rumen degradation characteristic in dairy cow, II: Starch. AJAS. Vol 11, 5:503-509

[43] Lii, C., V.M.F. Lai, dan M.C. Shen. 2004. Changes in retrogradation properties of rice starches with amylose content and molecular properties. Cereal Chemistry 81:392-398.

[44] Goelema, J. O., Spreeuwenberg, M. A. M., Hof, G., Van der Poel, A. F. B., Tamminga, S. 1998. Effect of pressure toasting on the rumen degradability and intestinal digestibility of whole and broken peas, lupins and faba beans and a mixture of these feedstuffs. Anim. Feed Sci. Technol., 76 (1-2): 35-50

[45] Goelema, J. O. 1999. Processing of legume seeds: effects on digestive behaviour in dairy cows. Cover design E. van Cleef, Wageningen/photograph cow: Veeteelt, Arnhem. Financial support for the publication of this thesis by Pre-Mervo U.A., Utrecht, is gratefully acknowledged. ISBN 90-5808-013-7.

[46] McDonald, P., Edwards, R. A., and Greenhalgh, J. F. D., 2002. Animal Nutrition. 6th Edition. Longman, London and New York. 543 p.

[47] Bach A., S. Calsamiglia M.D. Stern 2005. Nitrogen Metabolism in the Rumen. Journal of Dairy Science. 88. E9-E21.

[48] Lin C. And L. Kung, Jr. 1997. Heat treated soybeans and soybean meal in ruminant nutrition. American Soybean Association Technical Bulletin. Vol. AN15-1997 
[49] Lund, P., M.R. Weisbjerg, and T. Kristensen. 2004. The effect of heat treatment on degradability and microbial synthesis of protein in the rumen. Journal of Animal and Feed Sciences. 13: 143146.

[50] Wohlt, J.E., J.H. Clark and F.S. Blaisdell. 1976. Effect of sampling location, time, and method of sampling on concentration of ammonia nitrogen in rumen fluid. J. Dairy Sci. 59:459.

[51] Egan, A.R. 1980. Host animal-rumen relationships. Journal of Proceeding Nutrition and Society. 39:79.

[52] Paengkoum, P., Liang, J.B., Jelan, Z.A., dan Basery, M. 2006. Utilization of Steam-treated Oil Palm Fronds in Growing Saanen Goats: II. Supplementation with Energy and Urea. Journal of Animal Science. 19 (11): 1623-1631.

[53] Satter, L. D. dan Slyter. L.L. 1974. Effect of Amonia Concentration RumenMicrobial Protein Production In Vitro. Journal Nutrition. 32:194208.

[54] Hartutik, 1993. Nilai degradasi secara in sacco beberapa spesies hijauan sumber protein di daerah pegunungan kapur dan bukan kapur, Kabupaten Malang. Thesis. Program Pasca Sarjana UGM, Yogyakarta. 